\title{
Development of a rapid, sensitive and specific DNA-based method to detect Ralstonia solanacearum in potato for quarantine purposes
}

\author{
A.A.U. Perera ${ }^{1 *}$, O.V.D.S.J. Weerasena ${ }^{1}$, P.N. Dasanayaka ${ }^{2}$ and D.C. Wickramarachchi ${ }^{3}$ \\ ${ }^{I}$ Institute of Biochemistry, Molecular Biology and Biotechnology, University of Colombo, No. 90, Cumaratunga Munidasa Mawatha, Colombo 03. \\ ${ }^{2}$ Department of Botany, Faculty of Applied Sciences, University of Sri Jayewardenepura, Nugegoda. \\ ${ }^{3}$ Department of Statistics, Faculty of Applied Sciences, University of Sri Jayewardenepura, Nugegoda.
}

Revised: 14 September 2017; Accepted: 16 November 2017

\begin{abstract}
Bacterial wilt of potato is considered as one of the most destructive diseases of potato. The use of healthy seed potatoes is the most effective means to control the disease. Ralstonia solanacearum, the causal organism of bacterial wilt of potato, is considered as a quarantine pest in Sri Lanka. Therefore, there is a requirement to detect $R$. solanacearum in seed potatoes quickly and reliably for quarantine purposes. From this study, it was expected to present a rapid and effective DNA extraction method for PCR mediated detection of $R$. solanacearum in potato tubers for quarantine purposes. The sensitivity of the developed detection method was assessed. The present study developed a rapid, sensitive and specific DNAbased method for detection of $R$. solanacearum in potatoes with $10^{2}$ cfumL $^{-1}$ sensitivity. The developed detection method is user-friendly as it does not require more complicated and toxic chemical substances; consists of few steps of handling; and generates the result within one day, which makes this method more appropriate for quarantine purposes in Sri Lanka.
\end{abstract}

Keywords: Bacterial wilt, PCR, quarantine pest, Ralstonia solanacearum, Rsol fliC, seed potato.

\section{INTRODUCTION}

Potato (Solanum tuberosum L.) is the world's fourthlargest food crop, as it is an important staple food in the world after maize, wheat and rice. In Sri Lanka, potato is considered as an economically important vegetable crop. It is grown through vegetative propagation using potato tubers, which is known as seed potato. Bacterial wilt caused by Ralstonia solanacearum is a major problem confronted by the potato farmers in Sri Lanka. The estimated loss of potato yield in Sri Lanka due to bacterial wilt is around 5 to $25 \%$ (Kelaniyangoda et al., 1995), thus incurring heavy financial losses to the farmers. According to the Plant Protection Act No. 35 (Ministry of Agriculture, 1999), R. solanacearum is considered as a quarantine pest in Sri Lanka. Some of the strains of this species have not yet been reported; the existing strains also have a restricted distribution (Bandara, 1983; Kelaniyangoda, 1995) and the disease is officially controlled in the country. $R$. solanacearum biovar (bv) 1, which causes the disease in plants of the family Musaceae, mainly banana, plantain and Heliconia, has not yet been recorded in Sri Lanka. Mulberry strains of $R$. solanacearum only found in China that are described as bv5, are also not reported in Sri Lanka. $R$. solanacearum bv2, which causes the disease in potato, tomato and some other Solanaceae crops and weeds is restricted to the upcountry Wet Zone of Sri Lanka, while $R$. solanacearum bv3, which has a wide host range is distributed in the lower elevations of Sri Lanka (Bandara, 1983; Hayward, 1991; Kelaniyangoda, 1995). bv4 of $R$. solanacearum has been found only in Boralanda area in the upcountry Intermediate Zone of Sri Lanka (Kelaniyangoda, 1995). Introduction of other strains of $R$. solanacearum into the country may cause major outbreaks of diseases not only in potato but also in other crops belonging to the family Solanaceae and Musaceae causing huge economic losses.

\footnotetext{
*Corresponding author (aauperera@gmail.com; (iD https://orcid.org/0000-0003-0589-4325)
} 
Since $R$. solanacearum is soil borne and has a wide host range, it is challenging to manage the disease. Use of healthy seed potatoes is one of the most effective means to control the disease (Hayward, 1991). Although the pathogen is present in the soil, use of disease-free seed potatoes can significantly reduce disease incidence and allow growers to harvest a profitable crop (Champoiseau et al., 2009). Seed potato tubers should be obtained from disease-free crops.

Seed potato tubers are stored at low temperature ranges between 2 to $4{ }^{\circ} \mathrm{C}$ to maintain the correct physiological age until they are used for cultivation (Gamage et al., 2015). As a result, the loss of culturability while maintaining viability, a state known as the 'viablebut-not-culturable' (VBNC) state of $R$. solanacearum is achieved under low temperatures (Grey \& Steck, 2001), and it may complicate culture-based diagnosis (van Elsas et al., 2001). Indirect enzyme-linked immunosorbent assay (indirect ELISA) (Robinson-Smith et al., 1995; Caruso et al., 2002), immunofluorescent antibody staining (IFAS) (Janse, 1988) and immunofluorescent colony staining (IFCS) (Elphinstone et al., 1996) are some of the immunodiagnostic assays that use species-specific antibodies to detect $R$. solanacearum. Commercially available immunostrips (Agdia, CSL Pocket Diagnostics) can be used for rapid detection of the pathogen in the field or laboratory. However, the sensitivity of immunodiagnostic assays is limited to $10^{4}$ to $10^{6}$ cfumL $^{-1}$ (Elphinstone et al., 1996; Pradhanang et al., 2000). Further, no universal monoclonal antibodies for $R$. solanacearum are available and hence several bacterial species can show cross reactions with the antisera giving false positive results (Llop et al., 1999). Therefore, these techniques are not completely reliable. Fluorescent in situ hybridisation (FISH) (Wullings et al., 1998) utilises two probes constructed based on the $23 \mathrm{~S}$ rRNA region to detect bacteria in environmental samples. The main limitation of this method is that the probes are not specific for $R$. solanacearum because the probes have been designed for the bacterium as well as for two other closely related bacterial species. Loop-mediated isothermal amplification (LAMP) is another DNA based method to achieve gene replication without requiring denaturation of the template DNA. Although the method is rapid and $R$. solanacearum specific, the sensitivity of LAMP is limited to $10^{4}$ to $10^{6} \mathrm{cfumL}^{-1}$ (Kubota et al., 2008).

Polymerase chain reaction (PCR) based techniques are rapid, more sensitive and specific compared to immunodiagnostic methods and can be used for the detection of ultra-low populations of $R$. solanacearum in asymptomatic or latently infected potato tubers. Theoretically, PCR is able to detect as few as a single copy of target DNA. Due to the presence of polysaccharides and phenolic compounds in potato tuber extracts which act as inhibitors of Taq DNA polymerase in PCR (Grover et al., 2012), it is essential to isolate good quality bacterial DNA from potato tubers. In the detection of pathogens routinely for quarantine purposes, the DNA extraction method should be easy to handle with a few steps without complicated and toxic chemical substances; rapid; and should give sufficient amount of DNA without inhibitory substances of PCR.

The present study was focused on the development of a rapid and effective DNA extraction method for PCR mediated detection of $R$. solanacearum in potato tubers for quarantine purposes. Furthermore, the sensitivity of the developed detection method was assessed.

\section{METHODOLOGY}

\section{Sample collection}

Samples were collected from 3 potato-growing regions of the Badulla District in Sri Lanka: Bandarawela, Boralanda and Welimada. Wilted potato plants with symptoms were uprooted and the bacterial wilt was confirmed by cutting the wilted plants from the lower end of the stem and dipping in water to observe bacterial streaming. Fourteen potato tuber samples of the infected plants were collected. The samples were preserved in sealed polythene bags, taken to the laboratory and stored at $4{ }^{\circ} \mathrm{C}$.

\section{Development of a method to extract bacterial DNA from potato tubers}

The DNA extraction method, which was developed in this study was adapted from the CTAB based method described by Wilson (1997) that is used to extract DNA from pure bacterial cultures. The protocol was modified to extract bacterial DNA directly from potato tuber extracts, making the process simple and rapid.

Potato tubers were washed under running tap water to remove dirt and air-dried. The tubers were first cut longitudinally and cylindrical slices of $1 \mathrm{~cm}$ diameter and approximately $2 \mathrm{~mm}$ thickness were bored from the vascular region, where brown rot symptoms could be seen. Five surface sterilised tuber slices $(\sim 0.5 \mathrm{~g})$ from each tuber were cut into small pieces using a sterile scalpel and transferred into $1.5 \mathrm{~mL}$ microcentrifuge tubes. Lysis buffer [567 $\mu \mathrm{L}$ TE buffer $(\mathrm{pH} 8.0), 30 \mu \mathrm{L}$ 
$10 \% \mathrm{SDS}$ and $3 \mu \mathrm{L} 20 \mathrm{mgmL}^{-1}$ proteinase $\mathrm{K}$ ] was added, mixed by vortexing and incubated at $37^{\circ} \mathrm{C}$ for $15 \mathrm{~min}$. Thereafter, $100 \mu \mathrm{L}$ of $5 \mathrm{M} \mathrm{NaCl}$ was added, mixed thoroughly and incubated at $65^{\circ} \mathrm{C}$ for $5 \mathrm{~min}$. Then $80 \mu \mathrm{L}$ of pre-heated $\mathrm{CTAB} / \mathrm{NaCl}(10 \% \mathrm{CTAB}$ in $0.7 \mathrm{M} \mathrm{NaCl})$ solution was added and incubated at $65^{\circ} \mathrm{C}$ for another $10 \mathrm{~min}$. Subsequently, $6 \mu \mathrm{L}$ of $10 \mathrm{mgmL}^{-1} \mathrm{RNase}$ A was added and incubated at $37^{\circ} \mathrm{C}$ for $15 \mathrm{~min}$. Then the tubes were cooled to room temperature for $5 \mathrm{~min}, 200 \mu \mathrm{L}$ of potassium acetate $(60 \mathrm{~mL} 5 \mathrm{M}$ potassium acetate, $11.5 \mathrm{~mL}$ glacial acetic acid and distilled water up to $100 \mathrm{~mL}$ ) solution was added, mixed thoroughly by inverting the tubes for $5 \mathrm{~min}$ and centrifuged at $13500 \mathrm{rpm}$ for $10 \mathrm{~min}$. The supernatant of each sample was transferred into fresh $1.5 \mathrm{~mL}$ microcentrifuge tubes, $600 \mu \mathrm{L}$ of isopropanol was added and centrifuged at $13500 \mathrm{rpm}$ for $5 \mathrm{~min}$. The supernatant of each sample was decanted carefully by leaving the DNA pellet at the bottom of the tubes. The pellet was washed with $600 \mu \mathrm{L}$ of $70 \%$ ethanol and the tubes were centrifuged at $13500 \mathrm{rpm}$ for $1 \mathrm{~min}$. The supernatant was decanted and the pellet was air-dried for 15 min by keeping the tubes inverted on a tissue paper. The pellet of each sample was dissolved in $50 \mu \mathrm{L}$ of TE buffer ( $\mathrm{pH} 8.0)$ and DNA samples were stored at $-20^{\circ} \mathrm{C}$.

\section{PCR with Rsol $\_f i C$ primers}

R. solanacearum-specific primers, Rsol fliC (forward5' GAACGCCAACGGTGCGAACT 3' and reverse- 5' GGCGGCCTTCAGGGAGGTC 3') (Schonfeld et al., 2003), were used to amplify $400 \mathrm{bp}$ amplicon from the $f i C$ gene coding for the flagella subunit protein flagellin. PCR was performed in $25 \mu \mathrm{L}$ reaction mixtures containing $1 \times$ PCR buffer, $3.5 \mathrm{mM} \mathrm{MgCl}_{2}, 0.2 \mathrm{mM}$ dNTP mix, $0.1 \mu \mathrm{M}$ of each primer and $2 \mathrm{U}$ of Taq DNA polymerase (Promega, USA) per reaction with $1 \mu \mathrm{L}$ $(\sim 0.5 \mathrm{ng})$ of DNA extracted from 14 samples of potato tubers. Amplification was carried out in the thermal cycler (Veriti, Applied Biosystems, USA) programmed for the initial denaturation at $94{ }^{\circ} \mathrm{C}$ for $5 \mathrm{~min}$, followed by 35 cycles of denaturation at $94^{\circ} \mathrm{C}$ for $30 \mathrm{~s}$, annealing at $65^{\circ} \mathrm{C}$ for $2 \mathrm{~min}$, and extension at $72{ }^{\circ} \mathrm{C}$ for $1 \mathrm{~min}$ with a final extension at $72{ }^{\circ} \mathrm{C}$ for $10 \mathrm{~min}$. PCR products were electrophoresed in $1 \%(\mathrm{w} / \mathrm{v})$ agarose gel containing $0.5 \mathrm{mgmL}^{-1}$ ethidium bromide at a constant voltage of $50 \mathrm{~V}$ for $90 \mathrm{~min}$ and visualised under UV light using the gel documentation system (Quantum ST4 1100/ 20M, Vilber Lourmat, France).

\section{Determination of the sensitivity of the developed detection method using statistical analysis}

A 24 h old $R$. solanacearum reference culture (ATCC ${ }^{\circledR}$ BAA-1114 ${ }^{\mathrm{TM}}$, American Type Culture Collection, USA) grown in triphenyl tetrazolium chloride (TTC) broth was diluted by 10 folds using sterile distilled water to prepare a serial dilution up to $10^{-8}$. Bacterial culture $(100 \mu \mathrm{L})$ from each $10^{-4}$ to $10^{-8}$ dilution was transferred into three Petri plates and molten TTC agar medium was poured to prepare pour plates. The plates were incubated at $30^{\circ} \mathrm{C}$ for $24 \mathrm{~h}$. Plates containing colonies between 30 and 300 were considered for counting colonies using a digital colony counter (DC-3, Kayagaki, Japan). Colony forming units per $\mathrm{mL}\left(\mathrm{cfumL}^{-1}\right)$ of original culture was calculated by multiplying the number of colonies on the medium by the dilution factor [colony forming units per $\mathrm{mL}\left(\right.$ cfumL $\left.^{-1}\right)=$ number of colonies $\times$ dilution factor] (Bergey, 1994).

The original $R$. solanacearum broth culture and its dilutions, $10^{-2}, 10^{-4}, 10^{-6}$ and $10^{-8}$ prepared above were used for artificial inoculation into healthy potato tuber tissues as described in Ozakman and Schaad (2003). Healthy potato tubers were purchased from the local market, washed under running tap water and air-dried. The skin of one potato tuber was removed at the heel end, a cylindrical shaped core tissue was taken using a cork borer and cut transversely into cylindrical slices of $1 \mathrm{~cm}$ diameter and approximately $2 \mathrm{~mm}$ thickness. Five slices $(\sim 0.5 \mathrm{~g})$ of potato tuber core tissue were cut into small pieces using a sterile scalpel and transferred into $1.5 \mathrm{~mL}$ microcentrifuge tubes labelled as $10^{0}, 10^{-2}, 10^{-4}, 10^{-6}$ and $10^{-8}$. Exactly $1 \mathrm{~mL}$ of each dilution prepared above was transferred into the designated microcentrifuge tubes. Another 5 slices of potato tuber core tissue were cut into small pieces, transferred into another $1.5 \mathrm{~mL}$ microcentrifuge tube and $1 \mathrm{~mL}$ of sterile distilled water was added as the healthy control. The contents of the tubes were homogenised by vortexing and allowed to stand for $30 \mathrm{~min}$. The tubes were centrifuged at $12500 \mathrm{rpm}$ for $10 \mathrm{~min}$ and the supernatant was discarded. Ten replicates were done following the above procedure with 10 healthy potato tubers as described above.

Genomic DNA was extracted from artificially inoculated potato tuber tissues by following the developed DNA extraction method described above. PCRs were performed for extracted DNA with Rsol $f l i C$ primers and the PCR products were subjected to agarose gel electrophoresis to visualise as mentioned above.

If the specific amplicon was observed in agarose gel, it would be considered as $R$. solanacearum was detected by the developed DNA extraction method at the particular bacterial concentration (cfumL ${ }^{-1}$ ) and hence value ' 1 ', was given for those amplifications. Otherwise value ' 0 ' was given. The probability of detection of the bacterium at a particular bacterial concentration $\left(\mathrm{cfumL}^{-1}\right)$ was 
estimated by averaging the 10 responses. This method was repeated varying the bacterial concentration (cfumL ${ }^{-1}$ ) to estimate the probability of detection of the bacterium at each level of concentration (cfumL $L^{-1}$ ). The software Minitab version 16.0 (Minitab Inc., 2013) was used for logistic regression analysis to model the relationship between the probability of detection and the concentration $\left(\right.$ cfumL $^{-1}$ ). The value 0.1 was considered as the cut-off value for probability of detection of $R$. solanacearum. Thereby, the sensitivity of the developed detection method was determined using the fitted logistic regression model.

\section{RESULTS AND DISCUSSION}

All 14 DNA samples extracted from potato tubers, which showed disease symptoms produced the specific 400 bp size amplicon and hence were positive for $R$. solanacearum, while the negative control gave no amplicon (Figure 1). As a result, $100 \%$ of naturally infected potato tubers were detected as infected with $R$. solanacearum by the developed DNA extraction method. Based on this result, the method was selected as suitable to detect $R$. solanacearum in potato tubers.

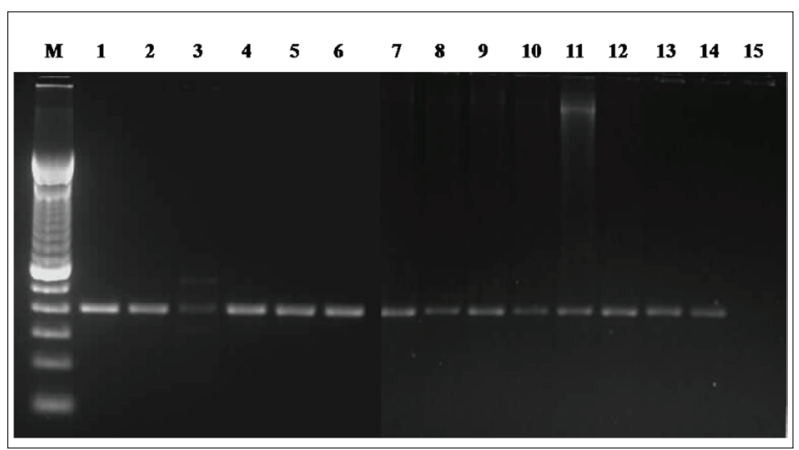

Figure 1: PCR products of genomic DNA extracted from naturally infected potato tubers with Rsol $f i c$ primers. Lane M: 100 bp ladder (Invitrogen, USA); Lane 1 to 6: samples from Bandarawela; Lane 7 to 8: samples from Boralanda; Lane 9 to 14: samples from Welimada; Lane 15: negative control with genomic DNA extracted from healthy potato tuber tissues. All fourteen DNA samples produced the specific $400 \mathrm{bp}$ size amplicon and hence were positive for R. solanacearum.

A fitted logistic model was constructed using logistic regression as given below to statistically analyse the sensitivity of the developed detection method (Agresti, 2013). $\ln \left(\frac{P_{i}}{1-P_{i}}\right)=\beta_{0}+\beta_{1} X_{i}$

where $P_{i}$ is the probability of detection at $i^{\text {th }}$ level of concentration (cfumL $L^{-1}$ ), $X_{i}$ is cfumL $L^{-1}$, and $\beta_{0}$ and $\beta_{1}$ are regression parameters. According to the results, the fitted logistic regression model obtained was:

$\ln \left(\frac{\mathrm{P}_{\mathrm{i}}}{1-\mathrm{P}_{\mathrm{i}}}\right)=-28.7756+10.5318 \log \left(\mathrm{X}_{\mathrm{i}}\right)$

The curve of probability of detection of the bacterium against $\log$ of cfumL $^{-1}$ (Figure 2) was obtained. The minimum level of bacterial concentration (cfumL $L^{-1}$ ), at where 0.1 probability of detection of $R$. solanacearum was possible by the developed detection method, was considered as the sensitivity of the developed detection method. When $P_{i}$ is 0.1 , the $X_{i}$ value was calculated using the above equation. Thereby, the sensitivity of the detection method developed in this study was 334 cfumL $^{-1}$.

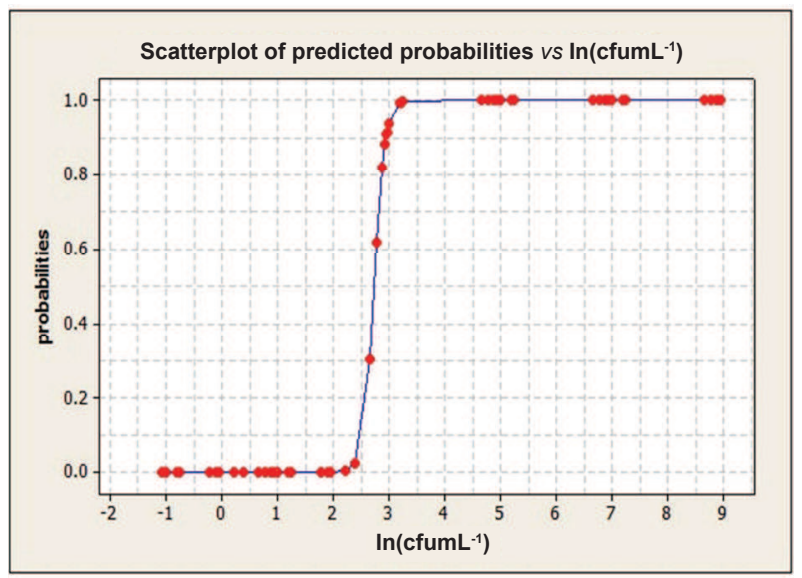

Figure 2: The curve obtained from the statistical analysis of results using the fitted logistic regression model showing the probability of detection of $R$. solanacearum by the method developed in the present study $v s \ln \left(\mathrm{cfumL}^{-1}\right)$. At the cutoff value of 0.1 for probability of detection of the bacterium, the level of bacterial concentration $\left(\mathrm{cfumL}^{-1}\right)$ was 334 .

The study was aimed at detecting $R$. solanacearum from asymptomatic potato tubers, which serve as seed potatoes. The method was adapted according to the quarantine requirements as well as to facilitate the performance of the test using minimum techniques. The method designed in this study consists of extracting DNA from potato tuber tissues and amplifying by PCR, thus increasing the 
sensitivity and specificity of detection. Finally, the study was focused on modifying a DNA extraction protocol with a few handling steps and less chemicals to be used in quarantine purposes.

The method does not need the use of more complicated chemicals such as liquid $\mathrm{N}_{2}$, which is generally used in plant DNA extraction protocols, thus the method has been simplified. The first step of the extraction protocol, the addition of lysis buffer to potato tuber tissues, enhances the diffusion of bacterial cells into the solution, disruption of the bacterial cells and dissociation of nucleic acids from the cells. In the second step of the extraction, CTAB, a cationic detergent, is used in the presence of a monovalent cation, $\mathrm{Na}^{+}$. It is used for denaturing and precipitating the cell wall lipopolysaccharides and proteins, which tend to interfere with the extraction. As the third step of the extraction RNase treatment, which is not a step in the Wilson's (1997) method is carried out to denature RNA to obtain good quality DNA for PCR. The fourth step, addition of potassium acetate instead of adding phenol, chloroform, and isoamyl alcohol, was performed to eliminate the high risk of using toxic chemicals (Llop et al., 1999; Grover et al., 2012). Under these conditions, the alkalinity of the mixture increases, causing hydrogen bonding between the bases of the ssDNA, and as a result the ssDNA can renature to dsDNA and dissolve easily in the solution. Simultaneously, SDS, denatured cellular proteins and polysaccharides attach together through hydrophobic interactions to form white precipitate. The precipitate can easily be separated from the DNA solution by centrifugation. But most of the centrifugation steps mentioned in the Wilson's method (1997) have been excluded to minimise cross contaminations at this point. The DNA extraction protocol developed in this study is user-friendly as the protocol will be applied routinely for analysing a large number of samples.

The PCR based detection method developed in this study is rapid, as it has only three phases: extraction of total genomic DNA directly from potato tuber tissues; PCR with Rsol_fliC primers; and agarose gel electrophoresis, and thus the results can be generated within a day. The sensitivity of the detection method was assessed statistically and sensitivity has reached $10^{2}$ cfumL $^{-1}$. The higher sensitivity of PCR detection could be due to the amplification of living and dead cells or VBNC bacterial cells (Josephson et al., 1993). The method is specific due to the usage of species-specific primers, thus it avoids interference due to the presence of saprophytic microorganisms in potato tubers. Cosolvents have been reported to be useful for some PCRs to avoid the production of non-specific bands upon gel electrophoresis (Varadaraj \& Skinner, 1994; Farell \& Alexandre, 2012) but in the current study there was no need of such additives or enzymes since the DNA extraction method was reproducible enough.

\section{CONCLUSION}

This study was able to develop a rapid, sensitive and specific DNA-based method, which can be applied to detect $R$. solanacearum in potato for quarantine purposes. The method was efficient for the detection of the bacterium with a sensitivity of $10^{2}$ cfumL $^{-1}$ in potato tubers. The developed detection method can be implemented to screen imported seed potatoes to detect the presence of $R$. solanacearum to prevent the entry of the pathogen into the country. Additionally, pathogen confirmation under field conditions can be performed using this method when potato plants show the symptoms. Consequently, using these findings, quarantine regulations and local seed certification procedures can be strengthened.

\section{Acknowledgement}

The authors wish to thank the National Research Council of Sri Lanka (Grant No. 11-099) for providing the financial support and the Regional Agriculture Research and Development Centre, Bandarawela for the assistance in sample collection.

\section{REFERENCES}

1. Agresti A. (2013). Categorical Data Analysis, $3^{\text {rd }}$ edition, pp. 165 - 197. John Wiley and Sons, Hoboken, New Jersey, USA.

2. Bandara J.M.R.S. (1983). Biotype distribution of vascular wilt pathogen Pseudomonas solanacearum in Sri Lanka. Journal of the National Science Council of Sri Lanka 11(1): $65-76$

3. Bergey H.D. (1994). Bergey's Manual of Determinative Bacteriology, $9^{\text {th }}$ edition (eds. J.G. Holt, N.R. Krieg, P.H.A. Sneath, J.T. Staley \& S.T. Williams). Williams and Wilkins, Baltimore, USA.

4. Caruso P., Gorris M.T., Cambra M., Palomo J.L., Collar J. \& Lopez M.M. (2002). Enrichment double-antibody sandwich indirect enzyme-linked immunosorbent assay that uses a specific monoclonal antibody for sensitive detection of Ralstonia solanacearum in asymptomatic potato tubers. Applied and Environmental Microbiology 68(7): $3634-3638$.

DOI: https://doi.org/10.1128/AEM.68.7.3634-3638.2002

5. Champoiseau P.G., Jones J.B. \& Allen C. (2009). Ralstonia solanacearum race 3 biovar 2 causes tropical losses and temperate anxieties. Plant Health Progress. 
DOI: https://doi.org/10.1094/PHP-2009-0313-01-RV

6. Elphinstone J.G., Hennessy J., Wilson J.K. \& Stead D.E. (1996). Sensitivity of different methods for the detection of Ralstonia solanacearum in potato tuber extracts. Bulletin OEPP/EPPO Bulletin 26: 663 - 678 .

DOI: https://doi.org/10.1111/j.1365-2338.1996.tb01511.x

7. Farell E.M. \& Alexandre G. (2012). Bovine serum albumin further enhances the effects of organic solvents on increased yield of polymerase chain reaction of GC-rich template. BMC Research Notes 5: 257 - 264.

DOI: https://doi.org/10.1186/1756-0500-5-257

8. Gamage G.G.S.U., Pushpika H.M.P., De Costa W.A.J.M. \& Nugaliyadde M.M. (2015). Effect of cold storage duration of seed tubers on the growth and yield performance of potato variety Granola. Annals of Sri Lanka Department of Agriculture 17: 111 - 113.

9. Grey B.E. \& Steck T.R. (2001). The viable but nonculturable state of Ralstonia solanacearum may be involved in long-term survival and plant infection. Applied and Environmental Microbiology 67(9): 3866 - 3872. DOI: https://doi.org/10.1128/AEM.67.9.3866-3872.2001

10. Grover A., Chakrabarti S.K., Azmi W. \& Khurana S.M.P. (2012). Rapid method for isolation of PCR amplifiable genomic DNA of Ralstonia solanacearum infested in potato tubers. Advances in Microbiology 2: 441 - 446. DOI: https://doi.org/10.4236/aim.2012.24056

11. Hayward A.C. (1991). Biology and epidemiology of bacterial wilt caused by Pseudomonas solanacearum. Phytopathology 29: 65 - 87 .

DOI:https://doi.org/10.1146/annurev.py.29.090191.000433

12. Janse J.D. (1988). A detection method for Pseudomonas solanacearum in symptomless potato tubers and some data on its sensitivity and specificity. Bulletin OEPP/EPPO Bulletin 18: 343 - 351 .

DOI: https://doi.org/10.1111/j.1365-2338.1988.tb00385.x

13. Josephson K.L., Gerba C.P. \& Pepper I.L. (1993). Polymerase chain reaction detection of nonviable bacterial pathogens. Applied and Environmental Microbiology 59: $3513-3515$.

14. Kelaniyangoda D.B. (1995). Identification of biovars of Ralstonia (Pseudomonas) solanacearum E.F. Smith in the upcountry of Sri Lanka. Tropical Agriculturist 150: 17 - 26.

15. Kelaniyangoda D.B., Tharmarajah S.K. \& Herat L.G. (1995). Effect of green manure, organic manure and chemicals on the incidence of bacterial wilt [Ralstonia (Pseudomonas) solanacearum $]$ in potato. Tropical Agriculturist 150: 35 - 47.

16. Kubota R., Vine B.G., Alvarez A.M. \& Jenkins D.M. (2008). Detection of Ralstonia solanacearum by loopmediated isothermal amplification. Phytopathology 98(9): $1045-1051$.

DOI: https://doi.org/10.1094/PHYTO-98-9-1045
17. Llop P., Caruso P., Cubero J., Morente C. \& Lopez M.M. (1999). A simple extraction procedure for efficient routine detection of pathogenic bacteria in plant material by polymerase chain reaction. Journal of Microbiological Methods 37: $23-31$.

18. Ministry of Agriculture (1999). Plant Protection Act, No. 35 of 1999. Acts and Regulations, Ministry of Agriculture, Sri Lanka. Available at http://extwprlegs1.fao.org/docs/ $p d f / s r l 37310 . p d f$, Accessed 5 October 2011.

19. Minitab Inc. (2013). MINITAB statistical software. Available at http://www.minitab.com, Accessed 23 August 2016.

20. Ozakman M. \& Schaad N.W. (2003). A real-time Bio-PCR assay for detection of Ralstonia solanacearum race 3 , biovar 2, in asymptomatic potato tubers. Canadian Journal of Plant Pathology 25: 232 - 239.

DOI: https://doi.org/10.1080/07060660309507075

21. Pradhanang P.M., Elphinstone J.G. \& Fox R.T.V. (2000). Sensitive detection of Ralstonia solanacearum in soil: a comparison of different detection techniques. Plant Pathology 49: 414 - 422.

DOI: https://doi.org/10.1046/j.1365-3059.2000.00481.x

22. Robinson-Smith A., Jones P., Elphinstone J.G. \& Forde S.M.D. (1995). Production of antibodies to Pseudomonas solanacearum, the causative agent of bacterial wilt. Food and Agricultural Immunology 7: 67 - 79.

DOI: https://doi.org/10.1080/09540109509354866

23. Schonfeld J., Heuer H., van Elsas J.D. \& Smalla K. (2003). Specific and sensitive detection of Ralstonia solanacearum in soil on the basis of PCR amplification of $f l i C$ fragments. Applied and Environmental Microbiology 69(12): 7248 7256.

DOI: https://doi.org/10.1128/AEM.69.12.7248-7256.2003

24. van Elsas J.D., Kastelein P., de Vries P.M. \& van Overbeek L.S. (2001). Effects of ecological factors on the survival and physiology of Ralstonia solanacearum bv.2 in irrigation water. Canadian Journal of Microbiology 47: 842 - 854. DOI: https://doi.org/10.1139/w01-084

25. Varadaraj K. \& Skinner D.M. (1994). Denaturants or cosolvents improve the specificity of PCR amplification of a $\mathrm{G}+\mathrm{C}$-rich DNA using genetically engineered DNA polymerases. Gene 140(1): $1-5$.

26. Wilson K. (1997). Preparation of genomic DNA from bacteria. Current Protocols in Molecular Biology, $2^{\text {nd }}$ edition (eds. F.M. Ausubel, R. Brent, R.E. Kingston, D.D. Moore, J.G. Seidman, J.A. Smith \& K. Struhl), pp. $2.4 .1-$ 2.4.5. John Wiley and Sons, Massachusetts, USA.

27. Wullings B.A., van Beuningen A.R., Janse J.D. \& Akkermans A.D.L. (1998). Detection of Ralstonia solanacearum, which causes brown rot of potato, by fluorescent in situ hybridization with 23S rRNA-targeted probes. Applied and Environmental Microbiology 64(11): $4546-4554$. 